\title{
Linkedln as a data source to rank universities \\ according to graduate's employability in top \\ companies
}

\section{Linkedln como fonte de dados para classificar as universidades de acordo com a empregabilidade dos licenciados em empresas de topo}

\author{
Alicia MORENO-DELGADO' (iD) 0000-0002-3425-061X \\ Enrique ORDUÑA-MALEA ${ }^{2}$ (iD 0000-0002-1989-8477 \\ Rafael REPISO' (iD) 0000-0002-2803-7505
}

\begin{abstract}
The purpose of this study is to determine the feasibility of ranking universities considering the number of its graduates employed in top companies (selective employability), as mapped through Linkedln. To achieve this, we analyzed the presence of 3,716,720 graduates from eighty Spanish universities hired by the Iberian Index companies, considering the percentages of graduates from each university working in those companies. The index obtained presents a short statistical range to correctly discriminate all universities. Moreover, the selective employability indicator is influenced by the distance between universities and companies (i.e., companies attract graduates from universities near their headquarters). This issue jeopardizes the use of this metric as a standalone ranking indicator. Finally, Linkedln shows several limitations as a data source (mainly representativeness, reliability, and accuracy).
\end{abstract}

Keywords: Employability. IBEX35. Social media. Spain. Higher Education Institutions. University rankings.

\section{Resumo}

O objetivo deste estudo é determinar a viabilidade de classificar as universidades segundo o número de egressos empregados em empresas de topo (empregabilidade seletiva) através do LinkedIn. Para isso, será analisada a presença de 3.716 .720 egressos de 80 universidades espanholas, contratados por empresas listadas no índice da bolsa espanhola lberian Index, através da porcentagem de egressos de cada uma das universidades contratados por essas empresas. O índice obtido apresenta um curto intervalo estatístico para discriminar corretamente todas as universidades. Além disso, o indicador seletivo de empregabilidade é influenciado pela distância entre universidades e empresas (ou seja, as empresas atraem licenciados de universidades localizadas perto da sua sede). Essa questão compromete a utilização da métrica como indicador autônomo de classificação. Finalmente, o Linkedln apresenta várias limitações como fonte de dados (principalmente representatividade, fiabilidade e exatidão).

Palavras-chave: Empregabilidade. IBEX35. Redes sociais. Espanha. Instituições de ensino superior. Classificação das universidades.

\footnotetext{
1 Universidad Internacional de La Rioja, Facultad de Empresa y Comunicación, Departamento de Comunicación. La Rioja, España.

2 Universitat Politècnica de València, Escola Tècnica Superior d'Enginyeria Informàtica, Departament de Comunicació Audiovisual, Documentació i Història de I'Art.. Camino de Vera, s/n., Valencia, 46022, Comunidad Valenciana, España. Correspondencia para/Correspondence to: E. ORDUÑA-MALEA. E-mail: <enorma@upv.es>.

Received on May 19, 2020 and approved on August 21, 2020.
}

Como citar este artigo/How to cite this article:

Moreno-Delgado, A.; Orduña-Malea, E.; Repiso, R. Linkedln as a data source to rank universities according to graduates'employability in top companies. Transinformação, v. 32, e200023, 2020. https://doi.org/10.1590/2318-0889202032e200023 


\section{Introduction}

Universities have undergone a series of changes that culminate in a new model in which higher education institutions move away from their eminently theoretical and academic natures and toward a more practical two-way approach. Within that approach, universities offer both professional training at the service of real business demands, on the one hand, and scientific research, on the other (Orduña-Malea, 2012). Within this new approach, a market-driven university has emerged (Prokou, 2008) with a commitment to enable its graduates to enter the job market and to position themselves in closer proximity to society, willing to meet the demands that society addresses to the university (Beraza; Rodríguez, 2007). As a result, companies play an important role in the higher education system.

This relationship between the university and the industry can be referred to as an attempt to adapt the former to the challenges of a contemporary society of knowledge so that its product - graduates - adapts as much as possible to the demands of the job market. As a consequence, if graduates do not adjust to the needs of the productive system, the investment in their training would represent a social and economic loss, since the expenditure would show no returns (Galcerán, 2010). This fact has generated political criticism and controversy, since the industry might overdetermine the educational and training activities that take place in universities (Levidow, 2002), leading to their marketization (Bendixen; Jacobsen, 2017).

The relevance of graduate employability in the current university context is thus evidenced. Unquestionably, the quality of education can provide graduates with more chances of being hired by companies, though this indicator is not the sole variable in defining employability. Still, employability-related data has long been used as potential indicators of the quality of the education received. Furthermore, employability might constitute an indicator for elitist hiring in certain top companies (i.e., selective employment rate), assuming that recruitment processes in those companies are more stringent. Following this logic, universities with a higher number of graduates preferred by top companies in recruiting processes would be seen as top-quality institutions by society at large.

One can find university rankings that include employability rates. These rankings reflect - or else, stimulate the increasing competition among universities to offer better job placements or internships in leading companies. In particular, it is worth mentioning that we can find global rankings based exclusively on data related to employability, such as the Global University Employability Survey \& Ranking and the QS Graduate Employability Rankings.

However, these rankings' coverage is low and insufficient to analyze entire national university systems. This is mainly due to the complexity of measuring universities by employability rates, given the absence of systematic and/or standardized protocols for obtaining data from graduates (Pavlin; Svetlik, 2014). Some universities have not implemented procedures to obtain this kind of data in a manageable way. Other institutions are inconsistent in their approach, which might vary from year to year, or from one department or institute within the university to the other.

While data may be available via external official bodies (governmental agencies and university associations), it also depends on the information provided by the universities. Moreover, general reports covering more than one institution tend to aggregate data, preventing comparative studies or fine-grained analyses at the institutional level. Information may also be obtained directly from the companies, which may use employees'resumés to create personnel databases. Nonetheless, only a few firms would maintain comprehensive databases, provide access to this information, or follow standardized procedures.

The launch of Linkedln opened a new door for monitoring employment data. For companies, the platform allows users to create different pages by typology (educational institution; freelance; government agency; non-profit; single owner; private; association). As to universities, the profile can only be created by the Linkedln team on request, and it is generally used as a marketing tool (Paniagua; Gómez, 2012).

Linkedln allows graduates to build and maintain a professional network, as well as to find and connect with former colleagues. It also helps them identify and obtain information about companies, find professionals in a particular sector, share ideas and information of interest with their network, and find new career opportunities. 
Linkedln constitutes a valuable repository of information to be used in the development of new services and information-based products (Case et al., 2012). Mijic (2012) suggested a systematic approach to the collection of data regarding alumni, given the importance of such information for universities and other institutions. Gonçalves et al. (2014) designed a tool to extract targeted information about Linkedln users while avoiding the need to consult the social media platform. Meanwhile, Li et al. (2016) analyzed and compared graduates' professional careers by creating database systems.

Linkedln allows users to include the university from which they graduated as well as their professional experience and current job when creating their profiles (Orduña-Malea et al., 2017; Komljenovic, 2019). Consequently, Linkedln can potentially provide massive data on universities'levels of employability. However, the suitability of Linkedln as a legitimate data source of graduates' employability still needs to be validated.

The overall objective of this study is to determine the feasibility of ranking universities considering the number of graduates employed in top companies by using Linkedln as a data source. In order to address this objective, we formulated the following research questions: (RQ1) According to Linkedln, Which universities have a higher number of graduates working in top companies? (RQ2) Are the university's longevity, legal status, teaching mode or Universityto-Company distance related to the number of graduates working in top companies? (RQ3) According to Linkedln, which top companies hire a larger number of graduates?

\section{Methodological Procedures}

To achieve the article's objective, a set of universities (the whole Spanish university system, composed by 83 institutions) and top companies (those listed in the IBEX35 stock market index) were considered as the object of a case study. The IBEX35 index comprises the 35 companies in Spain with the highest volume of trades in euros during the previous six months. This way, the number of graduates from Spanish universities working in these 35 companies constitutes a case study of a selective employability indicator.

With regards to the universities, data about their longevity (years since the foundation), teaching methodology (face-to-face or distance), legal status (public or private), and geographic location (Nomenclature des Unités Territoriales Statistiques-2 level) were obtained directly from the official university websites and the Spanish Official Registry of Universities, Centers and Titles. The total number of graduates (undergraduates and holders of Master's Degrees) from each of the 83 Spanish universities from 1985 to 2018 was obtained from the official statistics provided by the Spanish Ministry of Education and Vocational Training. Since the data is incomplete (it excludes doctorate degrees and all graduates before 1985), it can be used only as a rough approximation. The number of graduates from Spanish universities working for each of the 35 companies included in the IBEX35 index (2018 edition) was retrieved directly from the universities' official profile on Linkedln (alumni section).

With regards to the companies, the number of full-time employees and headquarters'location (Nomenclature des Unités Territoriales Statistiques-2 level) was retrieved from Yahoo Finance. The site of the company's headquarters has been taken as its location. Likewise, the cities where the headquarters of the company and the university were located were used to establish distances between universities and companies. The number of employees according to Linkedln was taken directly from the companies' official profiles.

No Linkedln profiles were found for one company (Actividades de Construcción y Servicios) and three institutions: Universidad Europea de Valencia (this organization has the same Linkedln profile as the Universidad Europea de Madrid), Universidad Eclesiástica San Dámaso (it has a Linkedln profile as a company but not as a university, and therefore graduate information cannot be accessed), and Universidad Fernando Pessoa-Canarias (with no Linkedln profile). All of them were excluded from the study. All the data was obtained between April and June 2018.

The IBEX35 rate (percentage of graduates from one university working in IBEX35 companies) was obtained for each university and then used as a selective employability indicator to rank Spanish institutions. A relative measure was used to make this indicator size-independent. 
In addition, a discriminant analysis was carried out to establish whether the teaching methodology and legal status were related to the number of graduates employed by the companies under study. Correlations were also conducted to determine whether the university's longevity and the university-to-company distance were related to the number of graduates employed by IBEX35 companies. The software XLStat was used for data processing and statistical analysis.

\section{Results}

\section{RQ1: Graduates from Universities}

LinkedIn records 3,716,720 graduate profiles, of which 97,748 correspond to graduates working in IBEX35 companies. The ranking of Spanish universities according to the IBEX rate is shown in Table 1. The IBEX rate is low ( mean=2.35; median=1.99) and quite homogeneous throughout all universities (standard deviation=1.29), with a maximum value of 7.13 (Internacional Menénez Pelayo) and a minimum value of 0.36 (Isabel I).

Table 1. Ranking of universities according to the IBEX35 rate (May 2018).

1 of 3

\begin{tabular}{|c|c|c|c|c|c|c|c|}
\hline Rank & $\begin{array}{c}\text { QS } \\
\text { Rank }\end{array}$ & University & Status & Graduates & $\begin{array}{l}\text { Alumni } \\
\text { Linkedln }\end{array}$ & $\begin{array}{l}\text { Alumni } \\
\text { IBEX35 }\end{array}$ & $\begin{array}{c}\text { IBEX35 } \\
\text { Rate (\%) }\end{array}$ \\
\hline 1 & & Internacional Menéndez Pelayo & Public & 4,736 & 2,103 & 150 & 7.13 \\
\hline 2 & & Pontificia Comillas & Private & 49,862 & 49,200 & 2,926 & 5.95 \\
\hline 3 & 5 & Politécnica de Madrid & Public & 140,061 & 154,073 & 8,410 & 5.46 \\
\hline 4 & & Pública de Navarra & Public & 36,203 & 16,667 & 852 & 5.11 \\
\hline 5 & 7 & Carlos III de Madrid & Public & 57,529 & 74,011 & 3,675 & 4.97 \\
\hline 6 & 10 & Alcalá & Public & 85,871 & 63,207 & 2,862 & 4.53 \\
\hline 7 & 8 & Autónoma de Madrid & Public & 152,386 & 119,224 & 4,864 & 4.08 \\
\hline 8 & & Cantabria & Public & 52,467 & 26,938 & 1,057 & 3.92 \\
\hline 9 & & Pontificia de Salamanca & Private & 42,069 & 22,037 & 821 & 3.73 \\
\hline 10 & & CEU San Pablo & Private & 35,621 & 50,412 & 1,871 & 3.71 \\
\hline 11 & & Deusto & Private & 71,531 & 50,322 & 1,827 & 3.63 \\
\hline 12 & & Politécnica de Cartagena & Public & 13,337 & 11,051 & 397 & 3.59 \\
\hline 13 & & Francisco de Vitoria & Private & 13,110 & 19,054 & 666 & 3.50 \\
\hline 14 & & La Coruña & Public & 78,375 & 32,311 & 1,123 & 3.48 \\
\hline 15 & 11 & Rey Juan Carlos & Public & 62,332 & 75,785 & 2,614 & 3.45 \\
\hline 16 & 15 & Pompeu Fabra & Public & 49,741 & 69,863 & 2,315 & 3.31 \\
\hline 17 & & Oviedo & Public & 134,831 & 56,037 & 1,856 & 3.31 \\
\hline 18 & & Alfonso X El Sabio & Private & 36,605 & 20,519 & 672 & 3.28 \\
\hline 19 & 2 & Complutense de Madrid & Public & 484,018 & 317,139 & 10,043 & 3.17 \\
\hline 20 & & Oberta de Catalunya & Public & 49,695 & 77,343 & 2,381 & 3.08 \\
\hline 21 & & Castilla-La Mancha & Public & 115,157 & 41,003 & 1,251 & 3.05 \\
\hline 22 & & Nacional de Educación a Distancia & Public & 139,338 & 108,196 & 3,255 & 3.01 \\
\hline 23 & & Valladolid & Public & 146,758 & 59,576 & 1,787 & 3.00 \\
\hline 24 & & Illes Balears & Public & 48,953 & 22,095 & 612 & 2.77 \\
\hline 25 & & León & Public & 69,229 & 30,816 & 837 & 2.72 \\
\hline 26 & & Distancia de Madrid & Private & 7,777 & 8,689 & 232 & 2.67 \\
\hline 27 & & Católica de Ávila & Private & 5,235 & 4,901 & 130 & 2.65 \\
\hline 28 & & Europea de Madrid & Private & 33,769 & 43,590 & 1,108 & 2.54 \\
\hline 29 & & Abad Oliva CEU & Private & 2,899 & 7,101 & 178 & 2.51 \\
\hline
\end{tabular}


Table 1. Ranking of universities according to the IBEX35 rate (May 2018).

\begin{tabular}{|c|c|c|c|c|c|c|c|}
\hline Rank & $\begin{array}{c}\text { QS } \\
\text { Rank }\end{array}$ & University & Status & Graduates & $\begin{array}{l}\text { Alumni } \\
\text { Linkedln }\end{array}$ & $\begin{array}{l}\text { Alumni } \\
\text { IBEX35 }\end{array}$ & $\begin{array}{c}\text { IBEX35 } \\
\text { Rate (\%) }\end{array}$ \\
\hline 30 & & Antonio de Nebrija & Private & 14,732 & 22,096 & 548 & 2.48 \\
\hline 31 & & Extremadura & Public & 109,754 & 32,829 & 813 & 2.48 \\
\hline 32 & 4 & Politècnica de Catalunya & Public & 130,935 & 112,681 & 2,701 & 2.40 \\
\hline 33 & & Loyola Andalucía & Private & 870 & 3,185 & 73 & 2.29 \\
\hline 34 & 13 & Zaragoza & Public & 169,610 & 68,491 & 1,518 & 2.22 \\
\hline 35 & & País Vasco & Public & 243,678 & 71,912 & 1,570 & 2.18 \\
\hline 36 & & Burgos & Public & 34,262 & 15,701 & 342 & 2.18 \\
\hline 37 & & Vigo & Public & 83,750 & 41,336 & 893 & 2.16 \\
\hline 38 & 1 & Navarra & Private & 65,374 & 44,164 & 917 & 2.08 \\
\hline 39 & & Rovira i Virgili & Public & 50,437 & 26,648 & 550 & 2.06 \\
\hline 40 & 3 & Barcelona & Public & 289,915 & 223,043 & 4,505 & 2.02 \\
\hline 41 & & San Jorge & Private & 2,642 & 5,301 & 104 & 1.96 \\
\hline 42 & & La Rioja & Public & 23,228 & 10,456 & 198 & 1.89 \\
\hline 43 & & Santiago de Compostela & Public & 145,895 & 61,054 & 1,151 & 1.89 \\
\hline 44 & & Camilo José Cela & Private & 38,698 & 29,092 & 546 & 1.88 \\
\hline 45 & & Europea Miguel de Cervantes & Private & 2,167 & 8,820 & 164 & 1.86 \\
\hline 46 & & Alicante & Public & 101,565 & 57,585 & 1,060 & 1.84 \\
\hline 47 & 6 & Autònoma de Barcelona & Public & 184,697 & 146,992 & 2,691 & 1.83 \\
\hline 48 & & Las Palmas de Gran Canaria & Public & 63,041 & 32,816 & 594 & 1.81 \\
\hline 49 & & Málaga & Public & 130,675 & 67,829 & 1,218 & 1.80 \\
\hline 50 & & Lleida & Public & 37,712 & 17,164 & 306 & 1.78 \\
\hline 51 & & Sevilla & Public & 251,460 & 132,072 & 2,314 & 1.75 \\
\hline 52 & & Jaén & Public & 56,239 & 23,295 & 404 & 1.73 \\
\hline 53 & 12 & Salamanca & Public & 146,830 & 84,287 & 1,459 & 1.73 \\
\hline 54 & & Internacional de La Rioja & Private & 30,030 & 20,642 & 355 & 1.72 \\
\hline 55 & & Cádiz & Public & 87,378 & 33,244 & 556 & 1.67 \\
\hline 56 & & Europea de Canarias & Private & 467 & 484 & 8 & 1.65 \\
\hline 57 & 9 & Politècnica de València & Public & 114,985 & 96,117 & 1,534 & 1.60 \\
\hline 58 & & Murcia & Public & 130,078 & 48,070 & 755 & 1.57 \\
\hline 59 & & Ramon Llull & Private & 59,590 & 32,636 & 512 & 1.57 \\
\hline 60 & & Huelva & Public & 41,262 & 17,067 & 262 & 1.54 \\
\hline 61 & & Girona & Public & 52,323 & 28,332 & 430 & 1.52 \\
\hline 62 & & Vic & Private & 18,799 & 11,923 & 178 & 1.49 \\
\hline 63 & 14 & València & Public & 255,533 & 109,597 & 1,631 & 1.49 \\
\hline 64 & & Miguel Hernández de Elche & Public & 31,201 & 21,728 & 296 & 1.36 \\
\hline 65 & & Granada & Public & 254,339 & 115,513 & 1,543 & 1.34 \\
\hline 66 & & La Laguna & Public & 86,420 & 34,121 & 448 & 1.31 \\
\hline 67 & & Córdoba & Public & 78,713 & 30,062 & 379 & 1.26 \\
\hline 68 & & Jaume I & Public & 36,367 & 15,933 & 197 & 1.24 \\
\hline 69 & & Pablo de Olavide & Public & 21,011 & 25,850 & 308 & 1.19 \\
\hline 70 & & Católica San Antonio & Private & 27,927 & 14,215 & 167 & 1.17 \\
\hline 71 & & Internacional de Valencia & Private & 9,533 & 4,760 & 54 & 1.13 \\
\hline 72 & & Almería & Public & 41,869 & 19,166 & 211 & 1.10 \\
\hline 73 & & Mondragon Unibertsitatea & Private & 16,944 & 9,994 & 101 & 1.01 \\
\hline
\end{tabular}


Table 1. Ranking of universities according to the IBEX35 rate (May 2018).

\begin{tabular}{|c|c|c|c|c|c|c|c|}
\hline Rank & $\begin{array}{c}\text { QS } \\
\text { Rank }\end{array}$ & University & Status & Graduates & $\begin{array}{l}\text { Alumni } \\
\text { Linkedln }\end{array}$ & $\begin{array}{l}\text { Alumni } \\
\text { IBEX35 }\end{array}$ & $\begin{array}{l}\text { IBEX35 } \\
\text { Rate (\%) }\end{array}$ \\
\hline 74 & & CEU Cardenal Herrera & Private & 17,485 & 15,483 & 157 & 1.01 \\
\hline 75 & & Internacional de Catalunya & Private & 11,562 & 10,620 & 107 & 1.01 \\
\hline 76 & & Company Institute & Private & 8,887 & 1,429 & 13 & 0.91 \\
\hline 77 & & Católica de Valencia & Private & 25,795 & 11,753 & 71 & 0.60 \\
\hline 78 & & Internacional de Andalucía & Private & 1,392 & 4,301 & 20 & 0.47 \\
\hline 79 & & Europea del Atlántico & Private & 736 & 3,758 & 16 & 0.43 \\
\hline 80 & & Isabel | & Private & 8,329 & 7,810 & 28 & 0.34 \\
\hline
\end{tabular}

Note: QS: Ranking positions from QS Graduate Employability Ranking (2018 Edition), available at: https://www.topuniversities. com/university-rankings/employability-rankings/2018.

Graduates: Number of graduates from Spanish universities (Graduate and Master degrees, from 1985-1986 to 2017-2018).

\section{RQ2: The university's dimensions and the IBEX35 rate}

The university's longevity shows a strong and significant correlation (Spearman, $a=0.1$ ) with the university's size. This way, the total number of graduates $(R=0.86 ; p$-value $=0.000)$, the number of graduates with a Linkedln profile $(R=0.74 ; p$-value $=0.000)$, and the number of graduates employed in IBEX35 companies $(R=0.74 ; p$-value $=0.000)$ are sensitive to long-lasting institutions. However, the university's longevity and the IBEX35 rate are weakly correlated ( $R=0.34 ; p$-value $=0.002$ ).

The strong correlation between the total number of graduates and the number of graduates with a Linkedln profile $(R=0.91 ; p$-value $<0.0001)$ created evidences that Linkedln can represent the size of the university.

As to the type of the university (Figure 1), we observe a higher average number of graduates from public universities than from private universities (1,631.3 and 501.7 graduates, respectively). The IBEX35 rate is higher in public universities (2.50) than in private universities (2.08). However, the Discriminant Analysis (Kullback's test) did not find statistical differences between private and public universities ( $p$-value $=0.941 ; \alpha=0.01$ ).

Regarding the university's teaching method (Figure 2), the average number of graduates is slightly higher in distance universities than in face-to-face ones (1,195 and 1,096, respectively), despite the low number of private institutions in the sample (6). However, when it comes to measuring the IBEX35 rate, it is slightly higher in face-to-face universities (2.38) than in distance universities (2.00). The discriminant Analysis (Kullback's test) did not find statistical differences between presence and face-to-face universities ( $p$-value $=0.730 ; \alpha=0.01$ ).

The regions of Madrid $(44,442$ graduates), Catalonia $(16,854)$, and Andalusia $(7,288)$ are the three main areas in numbers. An influence of the location of the companies'headquarters is observed. The region of Madrid concentrates a great percentage of IBEX35 companies (22). Catalonia experienced an exodus of companies due to the 1-O (October 1) political conflict (6 companies moved from Catalonia to other regions). However, Andalusia stands out as this region does not host any IBEX35 company.

\section{RQ3: Graduates in IBEX35 Companies}

According to Linkedln, a total of 651,128 employees are currently working in IBEX35 companies. Out of these, 15.0\% $(97,748)$ are graduates from Spanish universities.

Despite some outliers, the correlation (Spearman; $a>0.1$ ) between the size of the company (full-time employees) and the number of its employees on Linkedln is strong and significant ( $R=0.8 ; p$-value $<0.000)$. Also, the number of graduates from Spanish universities working in IBEX35 companies shows a significant correlation (Spearman; $a>0.1$ ) both with the number of full-time employees $(R=0.60 ; p$-value $=0.000)$ and with the number of employees with a Linkedln profile ( $R=0.80 ; p$-value $<0.0001)$. 

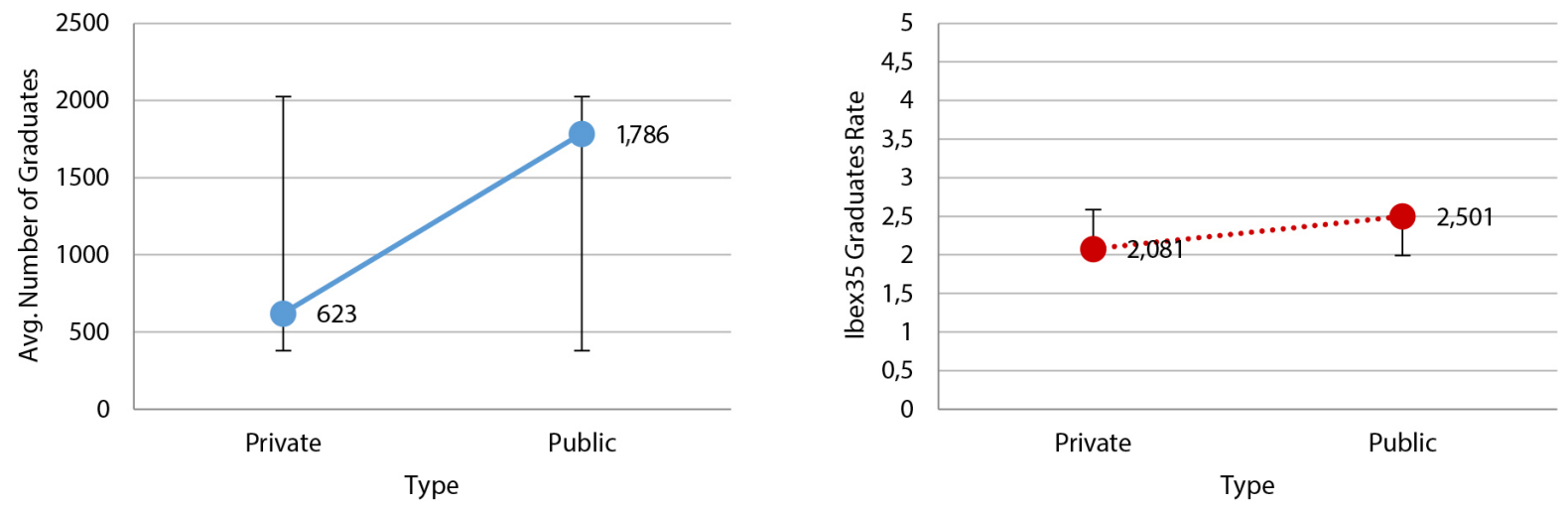

Figure 1. University type and IBEX35 rate.
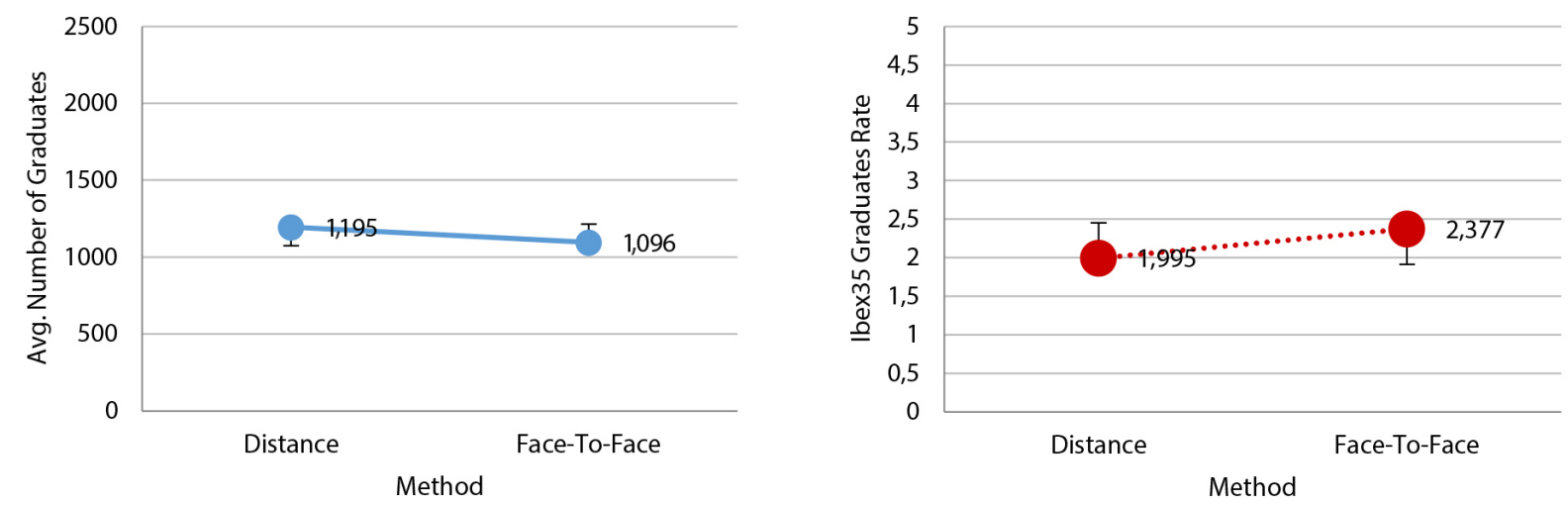

Figure 2. University teaching method and IBEX35 rate.

Telefónica (10,705), Banco Bilbao Vizcaya Argentaria $(10,119)$, and Indra $(10,090)$ are the companies employing more graduates from Spanish universities (Table 2). If the size of the company is considered, Mediaset (84.4\%) and Red Eléctrica (83.5\%) are the companies with the highest percentage of graduates employed.

The number of universities from which such graduates come varies widely from one company to the other (average=63.6; standard deviation=17.9). For example, Colonial and Acerinox employ graduates from few universities (15 and 24, respectively), while Telefónica, BBVA, and Mapfre employ graduates from a wide range of Spanish universities (79 universities each).

Table 2. Distribution of graduates employed by IBEX35 companies.

\begin{tabular}{|c|c|c|c|c|c|c|c|}
\hline Company & Sector & Location & $\begin{array}{l}\text { Full-Time } \\
\text { Employees }\end{array}$ & $\begin{array}{l}\text { Linkedln } \\
\text { Employees }\end{array}$ & $\begin{array}{l}\text { Number of } \\
\text { Graduates }\end{array}$ & $\%$ & $\begin{array}{l}\text { Number of } \\
\text { Universities }\end{array}$ \\
\hline Telefónica & $\begin{array}{l}\text { Communication services -Telecom } \\
\text { Services }\end{array}$ & Madrid & 118,022 & 90,857 & 10,705 & 11.8 & 79 \\
\hline BBVA & $\begin{array}{l}\text { Financial Services - Banks - } \\
\text { Diversified }\end{array}$ & $\begin{array}{l}\text { Basque } \\
\text { Country }\end{array}$ & 126,332 & 79,169 & 10,119 & 12.8 & 79 \\
\hline Indra & $\begin{array}{l}\text { Technology - Information } \\
\text { Technology Services }\end{array}$ & Madrid & 49,082 & 29,930 & 10,090 & 33.7 & 76 \\
\hline Banco Santander & $\begin{array}{l}\text { Financial Services - Banks - } \\
\text { Diversified }\end{array}$ & Cantabria & 201,017 & 102,206 & 8,429 & 8.2 & 77 \\
\hline Caixabank & $\begin{array}{l}\text { Financial Services - Banks - } \\
\text { Regional }\end{array}$ & Valencia & 35,669 & 9,742 & 6,812 & 69.9 & 76 \\
\hline Banco Sabadell & $\begin{array}{l}\text { Financial Services - Banks - } \\
\text { Regional }\end{array}$ & Valencia & 24,997 & 8,366 & 4,415 & 52.8 & 77 \\
\hline
\end{tabular}


Table 2. Distribution of graduates employed by IBEX35 companies.

\begin{tabular}{|c|c|c|c|c|c|c|c|}
\hline Company & Sector & Location & $\begin{array}{l}\text { Full-Time } \\
\text { Employees }\end{array}$ & $\begin{array}{l}\text { Linkedln } \\
\text { Employees }\end{array}$ & $\begin{array}{l}\text { Number of } \\
\text { Graduates }\end{array}$ & $\%$ & $\begin{array}{l}\text { Number of } \\
\text { Universities }\end{array}$ \\
\hline Mapfre & $\begin{array}{l}\text { Financial Services - Insurance - } \\
\text { Specialty }\end{array}$ & Madrid & 34,507 & 20,602 & 3,971 & 19.3 & 79 \\
\hline Repsol & Energy - Oil \& Gas Integrated & Madrid & 25,705 & 17,195 & 3,887 & 22.6 & 74 \\
\hline Inditex & Consumer Cyclical - Apparel Retail & Galicia & 167,897 & 40993 & 3,784 & 9.2 & 76 \\
\hline Acciona & $\begin{array}{l}\text { Industrials - Engineering \& } \\
\text { Construction }\end{array}$ & Madrid & 38,980 & 9,636 & 3,621 & 37.6 & 78 \\
\hline Bankia & $\begin{array}{l}\text { Financial Services - Banks - } \\
\text { Regional }\end{array}$ & Valencia & 16,051 & 6,085 & 3,603 & 59.2 & 74 \\
\hline Bankinter & $\begin{array}{l}\text { Financial Services - Banks - } \\
\text { Regional }\end{array}$ & Madrid & 8,512 & 5,006 & 3,127 & 62.5 & 77 \\
\hline Ferrovial & $\begin{array}{l}\text { Industrials - Infrastructure } \\
\text { Operations }\end{array}$ & Madrid & 78,316 & 22,710 & 2,991 & 13.2 & 74 \\
\hline Técnicas Reunidas & $\begin{array}{l}\text { Basic Materials - Industry and } \\
\text { Construction }\end{array}$ & Madrid & 8,971 & 6,581 & 2,908 & 44.2 & 72 \\
\hline Endesa & $\begin{array}{l}\text { Utilities - Utilities - Regulated } \\
\text { Electricity/Power }\end{array}$ & Madrid & 9,923 & 6,531 & 2,609 & 39.9 & 73 \\
\hline Gas natural & Utilities - Utilities - Regulated Gas & Madrid & 11,880 & 8,027 & 2,309 & 28.8 & 77 \\
\hline Iberdrola & Utilities - Utilities - Diversified & $\begin{array}{l}\text { Basque } \\
\text { country }\end{array}$ & 34,584 & 10,773 & 2,120 & 19.7 & 71 \\
\hline Melia Hotels & Consumer Cyclical - Lodging & $\begin{array}{l}\text { Balearic } \\
\text { Islands }\end{array}$ & 21,263 & 6,911 & 1,939 & 28.1 & 77 \\
\hline Siemens Gamesa & $\begin{array}{l}\text { Industrials - Specialty Industrial } \\
\text { Machinery }\end{array}$ & $\begin{array}{l}\text { Basque } \\
\text { country }\end{array}$ & 24,453 & 10,570 & 1,574 & 14.9 & 73 \\
\hline Aena & Industrials - Airports \& Air Services & Madrid & 7,629 & 3,410 & 1,458 & 42.8 & 72 \\
\hline Grifols & $\begin{array}{l}\text { Healthcare - Drug Manufacturers } \\
\text { - General }\end{array}$ & Catalonia & 22,000 & 7,332 & 1,403 & 19.1 & 63 \\
\hline Amadeus & $\begin{array}{l}\text { Technology - Information } \\
\text { Technology Services }\end{array}$ & Madrid & 15,967 & 12,555 & 967 & 7.7 & 62 \\
\hline Red Eléctrica & $\begin{array}{l}\text { Utilities - Utilities - Regulated } \\
\text { Electricity/Power }\end{array}$ & Madrid & 1,816 & 977 & 816 & 83.5 & 60 \\
\hline Dia & $\begin{array}{l}\text { Consumer Defensive - Discount } \\
\text { Stores }\end{array}$ & Madrid & 43,692 & 6,633 & 810 & 12.2 & 65 \\
\hline Arcelormittal & Basic Materials - Steel & Luxembourg & 208,583 & 30,206 & 762 & 2.5 & 55 \\
\hline Enagas & Utilities - Utilities - Regulated Gas & Madrid & 1,452 & 915 & 700 & 76.5 & 59 \\
\hline Mediaset & $\begin{array}{l}\text { Communication services - } \\
\text { Broadcasting }\end{array}$ & Madrid & 1,247 & 776 & 655 & 84.4 & 59 \\
\hline Cellnex & $\begin{array}{l}\text { Communication services - Telecom } \\
\text { Services }\end{array}$ & Madrid & 1,437 & 870 & 508 & 58.4 & 57 \\
\hline Viscofan & $\begin{array}{l}\text { Consumer Cyclical - Packaging \& } \\
\text { Containers }\end{array}$ & Navarra & 4,639 & 392 & 173 & 44.1 & 31 \\
\hline Abertis & $\begin{array}{l}\text { Industrials - Engineering \& } \\
\text { Construction }\end{array}$ & Madrid & 15,046 & 342 & 166 & 48.5 & 32 \\
\hline IAG & Industrials - Airlines & Madrid & 65,808 & 626 & 101 & 16.1 & 37 \\
\hline Acerinox & Basic Materials - Steel & Madrid & 6,809 & 189 & 90 & 47.6 & 24 \\
\hline Merlin & Real Estate - REIT - Diversified & Madrid & 176 & 104 & 78 & 75.0 & 31 \\
\hline Colonial Socimi & Real Estate - REIT - Office & Madrid & 200 & 477 & 48 & 10.1 & 15 \\
\hline
\end{tabular}

Source: Elaborated by the authors (2020).

Note: IAG: International Airlines Group. 


\section{Discussion}

The IBEX35 rate does not correlate with the university's size (number of graduates). We find small institutions with an elevated IBEX35 rate and big universities with less relevant scores. While this result is not necessarily negative, we find that those universities with the highest IBEX35 rates do not correspond to those appearing in the top positions in both Spanish (U-ranking, Conocimiento y Desarrollo) and global rankings (Times Higher Education World University Rankings, Quacquarelli Symonds World University Rankings, Academic Ranking of World Universities, Scimago Institutions Ranking, or Leiden Ranking), though these lists do not measure employability, but mainly the production of scientific research. The Quacquarelli Symonds Graduate Employability Ranking also offers a different order of Spanish universities. Therefore, the selective employability indicator used in this study offers distinct and supplementary information about the universities.

The university's longevity correlates with the total number of graduates working in IBEX35 companies, though this correlation disappears when the university's size is considered. This result aligns with previous research that highlights the relevance of longevity in the university's reputation (Drennan; Beck, 2001; Volkwein; Sweitzer, 2006; Repiso; Chaparro-Domínguez, 2018).

Evidence about the relationship between the university-to-company distance and the number of graduates employed by these companies was also obtained. This shows that companies that have their headquarters in the same area as the university tend to hire a larger number of its graduates, confirming similar earlier conclusions (Orduña-Malea et al., 2017).

The use of the IBEX35 as a test-bed of a selective employability indicator raises its own difficulties: First, it constitutes a very restrictive indicator. According to the data from Linkedln, $0.026 \%$ of graduates from Spanish universities is currently employed in IBEX35 companies. As a consequence, the indicator holds low sensitivity. The statistical range of the IBEX35 rate is 6.77, a low value to discriminate 80 universities. Moreover, other relevant sectors of the Spanish economy, such as public employment, education, and health are omitted. In this sense, the inclusion of other national (continuous market) and international (Eurostock, National Association of Securities Dealers Automated Quotations, etc.) stock market indexes is advisable.

Second, changes in the headquarters' location affect the accuracy of the indicator. One example is Banco Santander, which has its central office in Cantabria and its corporate headquarters in the region of Madrid. Future research must deal with the methodological challenges of determining whether the change of headquarters' locations led to a change in the employees' universities of origin.

Third, the companies in IBEX35 change over time. Twice a year, a new company may enter or leave this select club. In addition, the market area is highly volatile. Companies might merge, be absorbed by other companies, etc. Fourth, the sectors covered by IBEX35 companies are limited. Therefore, employability in these firms would depend on the Faculties and Centers where students graduate. This issue would discriminate universities not offering related degrees. Fifth, the occupations and positions of the graduates in IBEX35 firms should be considered. Sixth, top students might opt to work abroad, to create a start-up, or to become entrepreneurs.

How representative, reliable, accurate, and relevant the collected data from Linkedln is constitutes another discussion in point. First, Linkedln data must be representative of the size of universities, in terms of the number of graduates. In this sense, we find a strong correlation between the total number of graduates according to the official statistics and the number of graduates provided by LinkedIn $(R=0.92)$. This way, Linkedln reflects the size of the universities. However, there is no way to check whether the number of graduates provided by Linkedln $(3,716,720)$ is the real total value. This number represents approximately $61.3 \%$ of all graduates from Spanish universities if we consider the official statistics of the Spanish Ministry of Education and Vocational Training, excluding doctoral students.

Second, Linkedln data must be representative of the size of companies, in terms of their numbers of employees. The data shows a strong correlation between the number of full-time employees in a company and the number of employees with a Linkedln profile $(R=0.8)$. This way, Linkedln reflects the size of the companies. However, some 
firms (e.g., Inditex) have a low presence in Linkedln, which makes this platform unreliable for measuring alumni employment metrics for all companies.

Third, Linkedln data must be reliable. Despite the strong correlations obtained, important inconsistencies were also found (17 out of the 80 universities show a higher number of graduates with a Linkedln profile than total number of graduates since 1995). Moreover, not all Linkedln users link their place of work or study correctly, and the data provided by social network users is not verifiable. All this entails potential biases.

Fourth, Linkedln data must be as accurate as possible. However, Linkedln does not include the International Standard Classification of Occupations codes and hence it is not possible to evaluate whether the graduates are not overqualified for the positions they occupy. Fifth, the companies and universities with programs for their employees and/or graduates to create professional profiles may be over-represented. Sixth, different economic sectors might have different uses for and presences on Linkedln (e.g., communication or marketing labor markets have a much bigger presence than other industries).

\section{Conclusion}

In response to the RQ1, the Universidad Complutense de Madrid $(10,043)$ and the Universidad Politécnica de Madrid $(8,410)$ are the universities that provide the largest number of graduates to IBEX35 companies. When the university's size is considered (IBEX35 rate), two small institutions (Menéndez Pelayo and Pontificia Comillas) obtain the highest scores. With a few exceptions, the large traditional universities (e.g., Complutense de Madrid, Barcelona, Granada, Sevilla or Valencia) obtained lower scores.

In response to the RQ2, the number of graduates working in IBEX35 companies correlates both with the longevity and the size of the universities. On average, more graduates from distance universities are found in IBEX35 firms than from face-to-face universities, due to the existence of a long tail of presence-based institutions with few graduates employed by IBEX35 companies. As to the geographical variable, results show a high concentration of graduates employed by IBEX35 companies in the same areas where these companies are located. These results demonstrate that companies tend to hire graduates who have studied in universities placed in the regions where the companies have their headquarters. This can be explained by the local specialization of the universities and by the existence of fluent relations between companies and universities.

In response to the RQ3, Telefónica, Banco Bilbao Vizcaya Argentaria, and Indra are the companies that employ more graduates from Spanish universities. In terms of diversity, Telefónica, Aena, Indra, Dia, Cellnex, and Colonial are the ones that recruit graduates from a greater number of different universities.

In response to the general objectives proposed: First, the selective employability indicator used (number of graduates from Spanish universities working in IBEX35 companies) is not currently accurate enough to rank universities. However, the future inclusion of other companies listed in other share indexes might improve its value. Second, Linkedln currently exhibits several inconsistencies that jeopardize its use as a data source for graduates'employability. Nonetheless, Linkedln currently provides data about university-company connections through graduates, which is not available anywhere else, and its use in university rankings is promising if the issues raised in this study are overcome.

Despite all the limitations, the ranking obtained is a new tool that contains information of interest to classify the institutions, thus constituting a valuable resource when choosing universities for enrollment. Moreover, it would be an invaluable tool for any university brand when it comes to directing training policies, employability, insertion in the job market, and corporate reputation. In this sense, further research is deemed necessary to better comprehend and manage the employability data extracted from Linkedln.

\section{Contributors}

A. MORENO-DELGADO and E. ORDUÑA-MALEA contributed to the data analysis and interpretation. R. REPISO contributed to the study conception and design. 


\section{References}

Bendixen, C.; Jacobsen, J. C. Nullifying quality: the marketisation of higher education. Quality in Higher Education, v. 23, n. 1, p. 2034, 2017. Doi: https://doi.org/10.1080/13538322.2017.1294406.

Beraza, J. M.; Rodríguez, A. La evolución de la misión de la universidad. Revista de Dirección y Administración de Empresas, n. 14, p. 25-56, 2007. Disponible en: https://addi.ehu.es/ handle/10810/9908. Acesso en: 5 sept. 2020.

Case, T. et al. A Linkedln analysis of career paths of information systems alumni. Journal of the Southern Association for Information System, v. 1, n. 1, p. 1-13, 2012.

Drennan, L. T.; Beck, M. Teaching quality performance indicators: key influences on the UK universities' scores. Quality Assurance in Education, v. 9, n. 2, p. 92-102, 2001. Doi: http://dx.doi. org/10.1108/09684880110389663.

Galcerán, M. La mercantilización de la universidad. Revista Electrónica Interuniversitaria de Formación del Profesorado, v. 13, n. 2, p. 89-106, 2010. Disponible en: https://dialnet.unirioja.es/ descarga/articulo/3307348.pdf. Acesso en: 5 sept. 2020.

Gonçalves, G. R. et al. Gathering Alumni Information from a Web Social Network. In: 9th Latin American Web Congress, 2014, Ouro Preto. Proceedings Online [...]. Ouro Preto: IEEE, 2014. Doi: http://dx.doi.org/10.1109/LAWeb.2014.17.

Komljenovic, J. Linkedln, platforming labour, and the new employability mandate for universities. Globalisation, Societies and Education, v. 17, n. 1, p. 28-43, 2019. Doi: http://doi.org/10 .1080/14767724.2018.1500275.

Levidow, L. Marketizing higher education: neoliberal strategies and counter-strategies. In: Robins, K.; Webster, F. The virtual university? knowledge, markets and management. Oxford: Oxford University Press, 2002, p. 227-248.

Li, L. et al. Career trajectory analysis of information technology alumni: a Linkedln perspective. In: Annual Conference on Information Technology Education, 17., 2016, New York.
Proceedings Online [...]. New York: ACM Press, 2016. Doi: http:// dx.doi.org/10.1145/2978192.2978221.

Mijic, D. Design, implementation, and evaluation of a webbased system for alumni data collection. E-Society Journal: Research and Applications, v. 3, n. 2, p. 25-32, 2012. Available from: http://www.tfzr.rs/esociety/issues/eSocietyVol3No2.pdf. Acess on: Sept. 5, 2020.

Orduña-Malea, E. et al. From universities to private companies: a measurable route of Linkedln users. In: Cabrera, M.; Lloret, N. Digital tools for academic branding and self-promotion. Pennsylvania: Global, 2017.

Orduña-Malea, E. Propuesta de un modelo de análisis redinformétrico multinivel para el estudio sistémico de las universidades españolas. 2012. Tesis (Doctorado en Bibliotecología y Ciencias de la Información) - Universitat Politècnica de València, Valencia, 2012.

Paniagua, F. J.; Gómez, B. J. Hacia la comunicación 2.0: el uso de las redes sociales por parte de las universidades españolas. Revista ICONO14 Revista Científica de Comunicación y Tecnologías Emergentes, v. 10, n. 3, p. 346-364, 2012.

Pavlin, S.; Svetlik, I. Employability of higher education graduates in Europe. International Journal of Manpower, v. 35 n. 4, p. 418424, 2014.

Prokou, E. The emphasis on employability and the changing role of the university in Europe. Higher Education in Europe, v. 33, n. 4, p. 387-394, 2008. Doi: http://dx.doi.org/10.1080/0379 7720802522593.

Repiso, R.; Chaparro-Domínguez, M.-Á. Universidades españolas en la prensa extranjera. Análisis de su cobertura periodística. El Profesional de la Información, v. 27, n. 1, p. 86-94, 2018. Doi: http://dx.doi.org/10.3145/epi.2018.ene.08.

Volkwein, J. F; Sweitzer, K. V. Institutional prestige and reputation among research universities and liberal arts colleges. Research in HigherEducation, v. 47, n. 2, p. 129-148, 2006. Doi: http://dx.doi. org/10.1007/s11162-005-8883-5. 